De Block, M., L. Herrera-Estrella, M. Van Montagu, J. Schell, and P. Zambryski. 1984. Expression of foreign genes in regenerated plants and their progeny. EMBO J. 6:2513-2518.

Fraley, R.T., S.G. Rogers, R.B. Horsch, P.R. Sanders, J.S. Flick, S.P. Adams, M.L. Bittner, L.A. Brand, C.L. Fink, J.S. Fry, G.R. Galluppi, S.B. Goldberg, N.L. Hoffman, and S.C. Woo. 1983. Expression of bacterial genes in plant cells. Proc. Natl. Acad. Sci. USA 80:4803-4807.

Fromm, M., L.P. Taylor, and V. Walbot. 1985. Expression of genes transferred into monocot and dicot plants by electroporation. Proc. Natl. Acad. Sci. USA 82:5824-5828.

Herrera-Estrella, L., A. Depicker, M. Van Montagu, and J. Schell. 1983. Expression of chimeric genes transferred into plant cells using a Tiplasmid-derived vector. Nature 303:209-213.

Horsch, R.B., R.T. Fraley, S.G. Rogers, P.R. Sanders, A. Lloyd, and N.L. Hoffmann. 1984. Inheritance of functional foreign genes. Science 223:496498.

Klein, T.M., M. Fromm, A. Weissinger, D. Tomes, S. Schaaf, M. Sletten, and J.C. Sanford. 1988. Transfer of foreign genes into intact maize cells with high-velocity microprojectiles. Proc. Natl. Acad. Sci. USA 85:43054309.

Otten, L., H. De Greve, J.P. Hernalsteens, M. Van Montagu, O. Schieder, J. Straub, and J. Schell. 1981. Mendelian transmission of genes introduced into plants by the Ti plasmids of Agrobacterium tumafaciens. Mol. Gen. Genet. 183:209-213.

Owens, L.D. 1995. Overview of gene availability, identification, and regulation. HortScience 30:957-961.

Schroder, G., S. Waffenschnidt, E.W. Weiler, and J. Schroder. 1983. The Tregion of Ti-plasmids codes for an enzyme synthesizing indole-3-acetic acid. EMBO J. 2:403-409.

Thomashow, M.F., S. Hugly, W.G. Buchholz, and L.S. Thomashow. 1986. Molecular basis for the auxin independent phenotype of crown gall tumor tissue. Science 231:616-618.

Zambryski, P., H. Joose, C. Genetello, J. Leemans, M. Van Montagu, and J. Schell. 1983. Ti plasmid vector for the introduction of DNA into plant cells without alteration of their normal regeneration capacity. EMBO J. 2:21432150

\title{
Overview of Gene Availability, Identification, and Regulation
}

\author{
Lowell D. Owens \\ Plant Molecular Biology Laboratory, Agricultural Research Service, U.S. Department of Agriculture, \\ Beltsville, MD 20705
}

In 1981, the first transgenic plant capable of Mendelian transmission of an introduced gene was reported (Otten et al., 1981). In 1994, barely more than a dozen years later, the first genetically engineered major crop, bromoxynil-resistant cotton (Gossypium hirsutum L.), was deregulated by the U.S. Dept. of Agriculture for commercial production. Shortly thereafter, the first genetically engineered food product, the slow-softening Flavr-Savr tomato (Lycopersicon esculentum Mill.), was similarly approved for marketing. These historic milestones foretell a future in which gene transfer will be used increasingly for the introduction of important agronomic traits into crops. In planning for this future, it is useful to consider what genes are currently available for transfer, how new genes may be identified, and what elements of gene design affect expression of the transgene.

\section{GENE AVAILABILITY}

Table 1 lists more than three dozen genes that, while not exhaustive, indicate the range of genes that have been used to produce phenotypes of potential agronomic importance.

\section{Crop quality or yield}

The introduction of antisense genes for specific enzymes has been used to impart such diverse phenotypes as slow-softening tomatoes, which permit longer vine-ripening while retaining good shipping qualities (Hamilton et al., 1990; Oeller et al., 1991; Sheehy et al., 1988; Smith et al., 1988), and highly saturated canola (Brassica napus L.) oil, which provides a noncatalytically hydrogenated substitute for margarine (Knutzon et al., 1992; also see Ohlrogge, 1994). The use of sense constructs of other genes have increased the level of polyunsaturated fat in canola oil (Arondel et al., 1992; Okuley et al., 1994), produced sweeter tomatoes (Penarrubia et al., 1992), and altered photosynthate partitioning - owing to diminished regulation of transgene enzyme products in heterologous hosts (Micallef et al., 1993; Stark et al., 1992). Male-sterile plants, useful for hybrid seed production (Mariana et al., 1990), and novel flower colors (Meyer et al., 1992) also have been produced with sense constructs.

Received for publication 1 Feb. 1995. Accepted for publication 15 Feb. 1995. The cost of publishing this paper was defrayed in part by the payment of page charges. Under postal regulations, this paper therefore must be hereby marked advertisement solely to indicate this fact.

\section{Specialty products}

Genes from various sources have been used to produce specialty products. Poly- $\beta$-hydroxybutyrate, a thermoplastic feedstock (Poirier et al., 1992), and cyclodextrin, a complexing agent (Oakes et al., 1991), have been synthesized by plants carrying engineered bacterial genes. Engineered human genes have been used to cause production of human serum albumin (Sijmons et al., 1990) and the endorphin leuenkephalin (Vandekerckhove et al., 1989) in plants. Likewise, a plant lauroyl-ACP thioesterase gene placed under control of a highly active promoter was used to substantially shift the oil content of canola oil to lauric acid, an ingredient of soaps and cosmetics (see Ohlrogge, 1994; Voelker et al., 1992).

\section{Environmental stress tolerance}

Several transgenes were used to enhance tolerance to environmental stress. Production of the osmolyte mannitol imparted salt tolerance to tobacco (Nicotiana tabacum L.) (Tarczynski et al., 1993), while expression of a glycerol-3-phosphate acyltransferase gene from coldtolerant Arabidopsis thaliana (L.) Heynh. increased the proportion of cis-unsaturated fatty acids in membrane phosphatidylglycerol of coldsensitive tobacco - thereby increasing its tolerance to chilling (Murata et al., 1992). Freezing tolerance was enhanced by transgenes for either fish antifreeze protein (Hightower et al., 1991) or superoxide dismustase (McKersie et al., 1993; Van Camp et al., 1994). The latter enzyme destroys active-oxygen species generated in plants by freeze-thaw cycles or by certain herbicides, and confers herbicide and ozone tolerance, as well.

\section{Herbicide tolerance}

Engineered resistance to rapidly degraded herbicides - part of a strategy for environmentally safer weed control-has been achieved in two ways: by introducing bacterial genes that either degrade or detoxify the chemicals (2,4-dichlorophenoxy)acetic acid (2,4-D monooxygenase) (Streber and Willmitzer, 1989) and (bromoxynilspecific nitrilase) (Stalker et al., 1988), respectively, or, alternatively, by introducing a gene encoding a structurally altered target enzyme, 5enolpyruvylshikimate-3-P (EPSP) synthase (Comai et al., 1985) or acetolactate synthase, that no longer binds the herbicide (Haughn et al., 1987). 


\section{Pest resistance}

Transgenes conferring disease and insect resistance (Table 1, last category) is the largest and fastest growing category. There are numerous examples in which introduction of specific viral coat protein (see Beachey et al., 1990) or replicase genes (Donson et al., 1993; Golemboski et al., 1990) or viral-specific antisense constructs (see Agrawal, 1992) provided protection against groups of closely related viruses. A broader range of protection has been achieved by introducing the ribosome-inhibiting protein gene from pokeweed (Phytolacca americana L.) (Lodge et al., 1993).

Two approaches have been successful in conferring insect resistance. The first used genes whose products are toxic to feeding insects-Bt insecticidal protein (Perlak et al., 1991; Vaeck et al., 1987) and the cowpea [Vigna unguiculata (L.) Walp.] trypsin-inhibitor protein (Hilder et al., 1987). The second used a cytokinin-synthesis

Table 1. Genes introduced into crops and the phenotypes conferred.

\begin{tabular}{|c|c|c|c|}
\hline Transgene & Trait conferred & Crop modified & Reference $^{\mathrm{z}}$ \\
\hline \multicolumn{4}{|l|}{ Crop quality or yield } \\
\hline Antisense polygalacturonase & Slow-softening fruit & Tomato & Sheehy et al., 1988; Smith et al., 1988 \\
\hline Antisense ACC synthase & Delayed fruit ripening & Tomato & Oeller et al., 1991 \\
\hline Antisense ACC oxidase & Delayed fruit ripening & Tomato & Hamilton et al., 1990 \\
\hline Antisense stearoyl-ACP desaturase & High stearic (18:0) acid & Rapeseed, turnip rape & Knutzon et al., 1992; also see Ohlrogge, 1994 \\
\hline Omega-3 desaturase & High linolenic (18:3) acid & Arabidopsis & Arondel et al., 1992; Okuley et al., 1994 \\
\hline Monellin & Sweet protein & Tomato & Penarrubia et al., 1992 \\
\hline Maize sucrose-P synthase & High fruit yield & Tomato & Micallef et al., 1993 \\
\hline \multicolumn{4}{|l|}{ Escherichia coli ADP glucose } \\
\hline pyrophosphorylase & High starch/dry weight & Potato & Stark et al., 1992 \\
\hline Ribonuclease & Male sterility & Tobacco, rapeseed & Mariani et al., 1990 \\
\hline Dihdroflavonol reductase & Flower color & $\begin{array}{l}\text { Petunia (Petunia } \\
\text { hybrida Vilm.) }\end{array}$ & Meyer et al., 1992 \\
\hline \multicolumn{4}{|l|}{ Specialty products } \\
\hline $\begin{array}{l}\text { Acetoacetyl-CoA reductase } \\
\text { and PHB synthase }\end{array}$ & $\begin{array}{l}\text { Plastic (polyhydroxybutyrate) } \\
\text { production }\end{array}$ & Aradopsis & Poirier et al., 1992 \\
\hline Cyclodextrin glucosyl transferase & Cyclodextrin production & Potato & Oakes et al., 1991 \\
\hline Human serum albumin & Serum albumin production & Potato & Sijmons et al., 1990 \\
\hline Enkephalin pentapeptide & $\begin{array}{l}\text { Leu-enkephalin endorphin } \\
\text { production }\end{array}$ & Rapeseed & Vandekerckhove et al., 1989 \\
\hline Lauroyl-ACP thioesterase & High lauric (12:0) acid & Rapeseed & See Ohlrogge, 1994; Voelker et al., 1992 \\
\hline \multicolumn{4}{|l|}{ Environmental stress tolerance } \\
\hline Mannitol 1-P dehydrogenase & Salt tolerance & Tobacco & Tarczynski et al., 1993 \\
\hline Glycerol-3-P acyltransferase & Cold tolerance & Tobacco & Murata et al., 1992 \\
\hline Fish antifreeze protein & Freezing tolerance & Tobacco, tomato & Hightower et al., 1991 \\
\hline Superoxide dismutase & $\begin{array}{l}\text { Freezing, herbicide and } \\
\text { ozone tolerance }\end{array}$ & $\begin{array}{l}\text { Alfalfa (Medicago } \\
\text { sativa } \mathrm{L} .) \text {, tobacco }\end{array}$ & McKersie et al., 1993; Van Camp et al., 1994 \\
\hline \multicolumn{4}{|l|}{ Herbicide tolerance } \\
\hline 2,4-D monooxygenase & 2,4-D resistance & Tobacco & Streber and Willmitzer, 1989 \\
\hline Bromoxynil-specific nitrilase & Bromoxynil resistance & Tobacco & Stalker et al., 1988 \\
\hline Phosphinothricin acetyltransferase & $\begin{array}{l}\text { Gluphosinate (Basta) } \\
\text { resistance }\end{array}$ & Potato, tomato & De Block et al., 1987 \\
\hline Mutated EPSP synthase & $\begin{array}{l}\text { Glyphosate (Roundup) } \\
\text { resistance }\end{array}$ & Tobacco & Comai et al., 1985 \\
\hline Mutated acetolactate synthase & $\begin{array}{l}\text { Sulfonylurea (Glean, Oust) } \\
\text { resistance }\end{array}$ & Tobacco & Haughn et al, 1987 \\
\hline \multicolumn{4}{|l|}{ Pest resistance } \\
\hline Specific virus coat proteins & Resistance to related viruses & Various & See Beachy et al., 1990 \\
\hline Viral replicase & Resistance to related viruses & Tobacco & Donson et al., 1993; Golemboski et al., 1990 \\
\hline Viral-specific antisense & Virus resistance & Various & See Agrawal, 1992 \\
\hline $\begin{array}{l}\text { Pokeweed ribosome-inhibiting } \\
\text { protein }\end{array}$ & $\begin{array}{l}\text { Broad-spectrum virus } \\
\text { resistance }\end{array}$ & Tobacco, potato & Lodge et al., 1993 \\
\hline $\begin{array}{l}\text { Bacillus thuringiensis }(\mathrm{Bt}) \\
\text { insecticidal protein }\end{array}$ & $\begin{array}{l}\text { Resistance to lepidopteran } \\
\text { insects }\end{array}$ & Tobacco, tomato & Perlak et al., 1991; Vaeck et al., 1987 \\
\hline Cowpea trypsin inhibitor protein & Resistance to various insects & Tobacco & Hilder et al., 1987 \\
\hline Isopentenyl transferase (ipt) & Resistance to various insects & $\begin{array}{l}\text { Nicotiana } \\
\text { plumbaginifolia Viv. }\end{array}$ & Smigocki et al., 1993 \\
\hline Barley ribosome-inhibiting protein & $\begin{array}{l}\text { Resistance to Rhizoctonia } \\
\text { solani }\end{array}$ & Tobacco & Logemann et al., 1992 \\
\hline Bean chitinase & Resistance to $R$. solani & Tobacco, rapeseed & Broglie et al., 1991 \\
\hline Bacterial chitinase & $\begin{array}{l}\text { Resistance to Alternaria } \\
\text { longipes }\end{array}$ & Tobacco & Jones et al., 1988 \\
\hline Tobacco osmotin & $\begin{array}{l}\text { Resistance to Phytophtora } \\
\text { infestans }\end{array}$ & Potato & Liu et al., 1994 \\
\hline Bacteriophage lysozyme & $\begin{array}{l}\text { Resistance to Erwinia carotovora } \\
\text { subsp. atrospetica }\end{array}$ & Potato & During et al., 1993 \\
\hline Tomato Pto (a protein kinase) & $\begin{array}{l}\text { Resistance to Pseudomonas } \\
\text { syringae pv. tomato }\end{array}$ & Tomato & Martin et al., 1993 \\
\hline Barley $\alpha$-thionin & $\begin{array}{l}\text { Resistance to } P \text {. syringae } \\
\text { pv. syringae }\end{array}$ & Tobacco & Carmona et al., 1993 \\
\hline Insect cecropin & $\begin{array}{l}\text { Resistance to E. carotovora } \\
\text { and } P \text {. solanacearum }\end{array}$ & Potato, tobacco & Hassan et al., 1993; Jaynes et al., 1993 \\
\hline
\end{tabular}

${ }^{2}$ Generally, only the earliest reference for the introduction of a particular gene is cited. 
gene (ipt), under control of a wound-inducible promoter (Smigocki et al., 1993), to indirectly induce synthesis of one or more insecticidal metabolites (A. Smigocki, unpublished).

Resistance to certain fungal pathogens has been obtained by introducing a barley (Hordeum vulgare L.) gene for ribosome-inhibiting protein (Logemann et al., 1992) and by genes encoding chitinase (Broglie et al., 1991; Jones et al., 1988), osmotin (Liu et al., 1994), and lysozyme (During et al., 1993). Bacteria-resistance genes are less well known; however, a tomato Pto gene conferred resistance to Pseudomonas syringea pv. tomato when transferred to a susceptible isoline (Martin et al., 1993). Likewise, the introduction of the bactericidal polypeptide genes, $\alpha$-thionin (Carmona et al., 1993) and cecropin (Hassan et al., 1993; Jaynes et al., 1993), imparted resistance to certain bacterial pathogens.

\section{GENE IDENTIFICATION}

For identification and cloning purposes, genes may be classified into two groups: those for which a product is known and those for which there is no known product associated with the phenotype. All but two of the genes listed in Table 1 fall into the first group. Most mapped traits fall into the second.

Traditional methods of gene cloning, based on antibodies to purified proteins or knowledge of the protein's amino acid sequence, cannot be used with the second class. Consequently, two approaches have been used mainly for this class-gene tagging and map-based cloning.

\section{Cloning tagged genes}

In the gene-tagging approach, mutants are created by random insertion of a DNA tag - either modified T-DNA (transfer-DNA) (for example, see Okuley et al., 1994) or a transposon (for example, see Chuck et al., 1993). From these mutants, the tag, along with flanking plant DNA from the gene associated with the altered phenotype, is cloned by T-DNA/plasmid rescue or by hybridization-based screening using the tag as a probe. The main difficulties with gene tagging lie in producing many tag-transgenic plants with recognizable mutations and in efficiently screening plants for the desired mutant.

\section{Map-based cloning}

Map-based, or positional, cloning offers a direct approach to cloning mapped traits. As an example, cloning the tomato Pto gene, which confers resistance to races of $P$. syringae $\mathrm{pv}$. tomato carrying the avirulence gene avrPto (Martin et al., 1993), is summarized in Fig. 1. Briefly, progeny of crosses between resistant (Pto/Pto) and nearisogenic susceptible (pto/pto) lines of tomato were scored for restriction fragment length polymorphisms (RFLP) and resistance to infec-

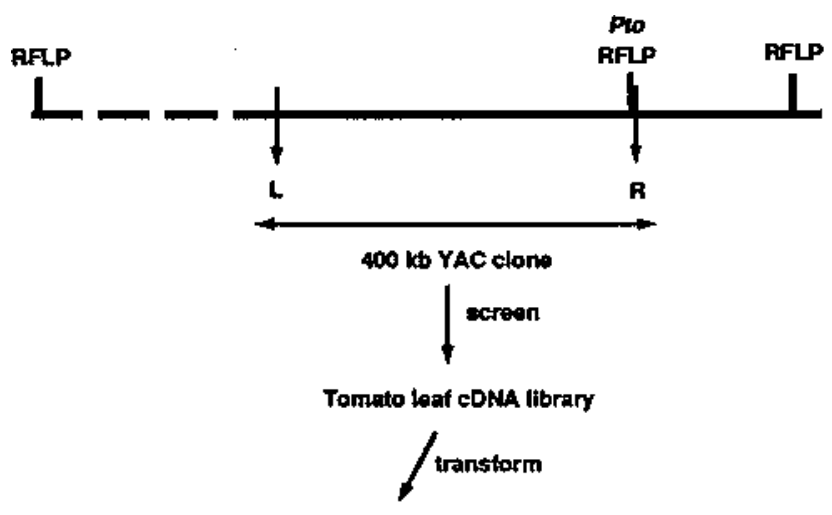

Euscapkible (pto) tomato

Posistant (Plo)

Fig. 1. Map-based cloning of the Pto gene from tomato (adapted from Martin et al., 1993). tion - the frequency of cosegregation reflecting their proximity on the chromosome. One RFLP marker cosegregated with the Pto locus and was used to screen a tomato yeast artificial chromosome (YAC) genomic library and identify a $400-\mathrm{kb}$ clone. To establish that the clone in fact spanned the Pto locus, end-specific probes were prepared to the left and right ends by inverse polymerase chain reaction (PCR) amplification and mapped. Having established that the right-end specific probe cosegrated with the Pto locus and the accompanying RFLP, the 400-kb DNA fragment was isolated and used to probe a tomato leaf cDNA library. A cDNA clone, so identified, cosegrated with Pto and, when transferred into the susceptible isoline, conferred resistance to the pathogen.

The power of this approach was illustrated by their findings that the Pto gene encodes a protein kinase-like protein and that DNA homologs were present in all other species examined. The latter finding points to the possibility that other species contain similar genes with similar functions and may, therefore, be easily cloned with the probes developed for tomato.

\section{GENE EXPRESSION AND REGULATION}

In constructing genes for use in plants, it is useful to consider whether high expression levels will be needed to impart the desired phenotype. Low-level expression of genes encoding novel enzymes, for example, may be sufficient to achieve the desired end, whereas higher expression of genes encoding pesticidal toxins may be required to provide adequate control of the target pest.

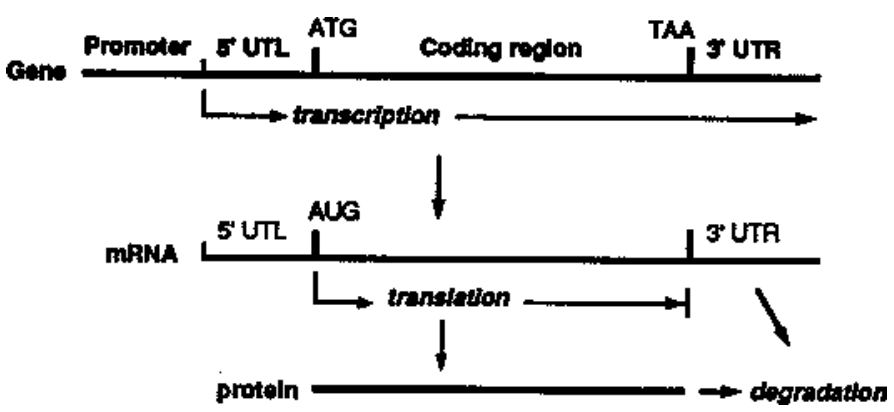

Fig. 2. Schematic representation of gene expression.

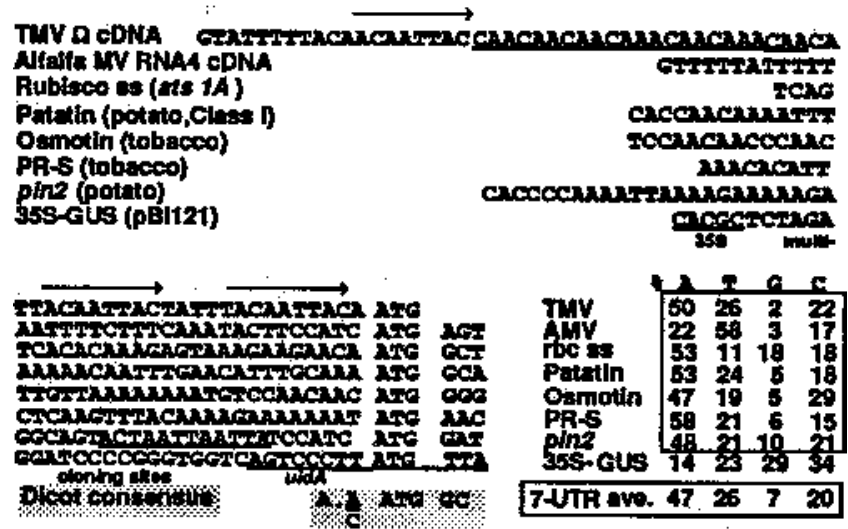

Fig. 3. Nucleotide sequence of the 5' UTRs of seven highly expressed, dicot nuclear or viral genes and of the 35S-GUS construct pBI121. The 5' UTR sequences listed are from cDNAs of tobacco mosaic virus $\Omega$ sequence (Gallie and Walbot, 1992) and alfalfa mosaic virus RNA 4 (Jobling and Gehrke, 1987), and from genes encoding Rubisco ss from Arabidopsis thaliana (Wong et al., 1992), Class I patatin from potato (Rocha-Sosa et al., 1989), the pathogenesis-related (PR) proteins osmotin (Raghothama et al., 1993) and PR-S (van Kan et al., 1989) from tobacco, and proteinase inhibitor II protein Pin2 from potato (Keil et al., 1986). Repeated sequences in TMV $\Omega$ cDNA are indicated by arrows and underlining. The dicot consensus for ATG initiation codon context (Cavener and Ray, 1991) is shaded. 
The level of gene-product accumulation will reflect not only the rates of transcription and translation, but also the rates of mRNA and product degradation (Fig. 2). Gene-construct features that affect each of these processes will be considered.

\section{Transcription}

The highly active $35 \mathrm{~S}$ promoter from cauliflower mosaic virus (Odell et al., 1985) has been used widely to provide high constitutive transcriptional rates. Where high transient expression is called for, examples of promoters that have been used include those from proteinase inhibitor II (pin2) (Lorberth et al., 1992), osmotin (Xu et al., 1994), or PR-S (van Kan et al., 1989). These provide high, but temporal, transcription rates when induced by certain environmental stimuli, such as wounding or infection by specific pathogens. The pin 2 promoter is also constitutively expressed in potato (Solanum tuberosum L.) tubers.

\section{Translation}

Translational efficiency is affected by the composition of the $5^{\prime}$ untranslated region ( $5^{\prime}$ UTR) and AUG context of the mRNA transcript. An analysis of cDNA sequences of the $5^{\prime}$ UTRs of seven highly expressed dicot nuclear or viral genes (Fig. 3, boxed) reveals that all are A- or T-rich (average of $73 \% \mathrm{~A}+\mathrm{T}$ ), as compared to a random sample of 79 plant 5' UTRs analyzed by Joshi (1987). By way of contrast, a commonly used construct of the $35 \mathrm{~S}$ promoter from cauliflower mosaic virus, pBI121 (Clontech, Palo Alto, Calif.), uses a less-than-optimal 5'UTR. It consists of only five nucleotides from the 35S 5'UTR (Fig. 3, underlined), a synthetic 22-nucleotide multicloning site and an 8-nucleotide sequence, and ATG translational start signal from the uidA gene encoding $\beta$-glucuronidase (GUS) from Escherichia coli. This $5^{\prime}$ UTR is relatively AT-poor ( $37 \%$ A+T). Further, the ATG context of the PBI121 construct (CTT ATG TT) differs considerably from the dicot consensus A_A/C ATG GC (Fig. 3, shaded) (Cavener and Ray, 1991) and is probably suboptimal for translational efficiency (Taylor et al., 1987).

Stem-and-loop secondary structures in 5' UTRs may, if sufficiently stable, reduce translational efficiency (Kozak, 1986). Ingersoll et al. (1994) observed a 50\% decrease in GUS expression when a pin2 promoter and 5'UTR, joined to the GUS coding region, was compared with a similar construct in which a 12-nucleotide, AT-rich sequence (Fig. 3, underlined) was replaced with an 8-nucleotide sequence that was both AT-poor and capable of forming a hairpin. The hairpin structure was speculated to have caused a part of the diminished expression.

Translational efficiency also is affected by the makeup of the coding region. For example, Perlak et al. (1991) were able to greatly increase the translational efficiency of mRNA encoding the insecticidal protein from Bacillus thuringiensis by completely synthesizing/ modifying the coding region according to certain rules. The coding sequence was altered to use plant-preferred codons (Murray et al., 1989) and to avoid repeats of the mRNA instability sequence ATTTA (Green, 1993) and potential polyadenylation signal sequences AATAAA and AATAAT. With these modifications, the levels of insecticidal protein in transgenic plants carrying the modified gene were 100-fold higher than in plants carrying the wild-type gene.

\section{Protein stability}

Finally, the level of gene-product accumulation will be affected by stability of the product to degradative enzymes present in the target locale. We have studied the stability of the bactericidal polypeptide cecropin B (Boman and Hultmark, 1987) and a synthetic analog MB39 (Fig. 4) in intercellular fluids extracted from leaves of 10 crops (Mills et al., 1994; Owens and Heutte, 1994). Protein stabilities were markedly affected by the crop source of intercellular fluid and the polypeptide sequence. The half-life of cecropin B ranged from $3 \mathrm{~min}$ in potato to $25.5 \mathrm{~h}$ in rice (Oryza sativa $\mathrm{L}$.) intercellular fluid, whereas that of MB39 ranged from $17 \mathrm{~min}$ in potato to $10.3 \mathrm{~h}$ in maize (Zea mays L.) fluid. MB39 was more stable in intercellular fluids from nine of the 10

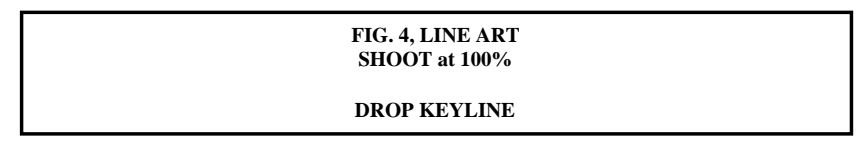

Fig. 4. Amino acid sequence of cecropin B (Boman and Hultmark, 1987) and a synthetic homolog MB39 of similar bioactivity (unpublished). Shading indicates structural differences.

species examined-its half-life averaging 2.5 times that of cecropin $B$. Clearly, small differences in structure (Fig. 4) can confer substantial increases in stability. This effect suggests the possibility of modifying protein genes to enhance product stability.

\section{CONCLUSION}

Increasingly in the future, gene transfer will be the method of choice for introducing important, value-adding genes into elite lines of horticultural crops. Although other classes of organisms will continue to be an important source of genes for transfer to plants, techniques for cloning plant genes currently known only by phenotype will provide an ever-growing new source of genes for this purpose. Knowledge of the molecular biology of gene transcription and translation now enable modification of transgenes to optimize their expression in the target plant or tissue. Further knowledge of the relationship between protein structure and susceptibility to protease action may guide the engineering of genes to enhance protein accumulation levels.

\section{Literature Cited}

Agrawal, S. 1992. Antisense oligonucleotides as antiviral agents. Trends in Bio/Technology 10:152-158.

Arondel, V., B. Lemieux, I. Hwang, S. Gibson, H.M. Goodman, and C.R. Somerville. 1992. Map-based cloning of a gene controlling omega-3 fatty acid desaturation in Arabidopsis. Science 28:1353-1354.

Beachy, R.N., S. Loesch-Fries, and N.E. Tumer. 1990. Coat protein-mediated resistance against virus infection. Annu. Rev. Phytopathol. 28:451-474.

Boman, H.G. and D. Hultmark. 1987. Cell-free immunity in insects. Annu. Rev. Microbiol. 41:103-126.

Broglie, K., I. Chet, M. Holliday, R. Cressman, P. Biddle, S. Knowlton, C.J. Mauvais, and R. Broglie. 1991. Transgenic plants with enhanced resistance to the fungal pathogen Rhizoctonia solani. Science 254:1194-1197.

Carmona, J.J., A. Molina, J.A. Fernandez, J.J. Lopez-Fando, and F. GarciaOlmedo. 1993. Expression of the $\alpha$-thionin gene from barley in tobacco confers enhanced resistance to bacterial pathogens. Plant J. 3:457-462.

Cavener, D.R. and S.C. Ray. 1991. Eukaryotic start and stop translation sites. Nucleic Acids Res. 19:3185-3192.

Chuck, G., T. Robbins, C. Nijjar, E. Ralston, N. Courtney-Gutterson, and H.K. Dooner. 1993. Tagging and cloning of a petunia flower color gene with the maize transposable element Activator. Plant Cell 5:371-378.

Comai, L., D. Facciotti, W.R. Hiatt, G. Thompson, R. Rose, and D. Stalker. 1985. Expression in plants of a mutant aroA gene from Salmonella typhimurium confers tolerance to glyphosate. Nature 317:741-744.

De Block, M., J. Botterman, M Vandewiele, J. Dockx, C. Thoen, V. Gossele, N. Rao Movva, C. Thompson, M. Van Montagu, and J. Leemans. 1987. Engineering herbicide resistance in plants by expression of a detoxifying enzyme. EMBO J. 6:2513-2518.

Donson, J., C.M. Kearney, T.H. Turpen, I.A. Khan, G. Kurath, A.M. Turpen, G.E. Jones, W.O. Dawson, and D.J. Lewandowski. 1993. Broad resistance to tobamoviruses is mediated by a modified tobacco mosaic virus replicase transgene. Mol. Plant-Microbe Interactions 6:635-642.

During, K., P. Porsch, M. Fladung, and H. Lorz. 1993. Transgenic potato plants resistant to the phytopathogenic bacterium Erwinia carotovora. Plant J. 3:587-598.

Gallie, D.R. and V. Walbot. 1992. Identification of the motifs within the tobacco mosaic virus 5 '-leader responsible for enhancing translation. Nucleic Acids Res. 20:4631-4638.

Golemboski, D.B., G.P. Lomonossoff, and M. Zaitlin. 1990. Plants transformed with a tobacco mosaic virus non-structural gene sequence are resistant to the virus. Proc. Natl. Acad. Sci. USA 87:6311-6315.

Green, P.J. 1993. Control of mRNA stability in higher plants. Plant Physiol. 102:1065-1070.

Hamilton, A.J., G.W. Lycett, and D. Grierson. 1990. Antisense gene that inhibits synthesis of the hormone ethylene in transgenic plants. Nature 346:284-287.

Hassan, M., S.S. Sinden, R.S. Kobayashi, R.O. Nordeen, and L.D. Owens. 1993. Transformation of potato (Solanum tuberosum) with a gene for an 
anti-bacterial protein, cecropin. Acta Hort. 336:127-131.

Haughn, G.W., J. Smith, B. Mazur, and C. Somerville. 1987. Transformation with a mutant Arabidopsis acetolactate synthase gene renders tobacco resistant to sulfonylurea herbicides. Mol. Gen. Genet. 211:266-271.

Hightower, R., C. Baden, E. Penzes, P. Lund, and P. Dunsmuir. 1991. Expression of antifreeze proteins in transgenic plants. Plant Mol. Biol. 17:1013-1021.

Hilder, V.A., A.M.R. Gatehouse, S.E. Sheerman, R.F. Barker, and D. Boulter. 1987. A novel mechanism of insect resistance engineered into tobacco. Nature 330:160-163.

Ingersoll, J.C., T.A. Heutte, and L.D. Owens. 1994. Optimized transient expression in sugarbeet suspension cells for promoter analysis. Plant Physiol. Suppl. 105:137.

Jaynes, J.M., P. Nagpala, L. Destefano-Beltran, J.H. Huang, J-H. Kim, T. Denny, and S. Cetiner. 1993. Expression of a cecropin B lytic peptide analog in transgenic tobacco confers enhanced resistance to bacterial wilt caused by Pseudomonas solanacearum. Plant Sci. 89:43-53.

Jobling, S.A., and L. Gehrke. 1987. Enhanced translation of chimaeric messenger RNAs containing a plant viral untranslated leader sequence. Nature 325:623-625.

Jones, J.D.G., C. Dean, D. Gidoni, D. Gilbert, D. Bond-Nutter, R. Lee, J. Bedbrook, and P. Dunsmuir. 1988. Expression of bacterial chitinase protein in tobacco leaves using two photosynthetic gene promoters. Mol. Gen. Genet. 212:536-542.

Joshi, C.P. 1987. An inspection of the domain between putative TATA box and translation start site in 79 plant genes. Nucleic Acids Res. 16:6643-6653.

Keil, M., J. Sanchez-Serrano, J. Schell, and L. Willmitzer. 1986. Primary structure of a proteinase inhibitor II gene from potato (Solanum tuberosum). Nucleic Acids Res. 14:5641-5650.

Knutson, D.S., G.A. Thompson, S.E. Radke, W.B. Johnson, V.C. Knauf, and J.C. Kridl. 1992. Modification of Brassica seed oil by antisense expression of a steroyl-acyl carrier protein desaturase gene. Proc. Natl. Acad. Sci. USA 89:2624-2628.

Kozak, M. 1986. Influences of mRNA secondary structure on initiation by eukaryotic ribosomes. Proc. Natl. Acad. Sci. USA 83:2850-2854.

Liu, D., K.G. Raghothama, P.M. Hasegawa, and R.A. Bressan. 1994. Osmotin overexpression in potato delays development of disease symptoms. Proc. Natl. Acad. Sci. USA 91:1888-1892.

Lodge, J.K., W.K. Kaniewski, and N.E. Tumer. 1993. Broad-spectrum virus resistance in transgenic plants expressing pokeweed antiviral protein. Proc. Natl. Acad. Sci. USA 90:7089-7093.

Logemann, J., G. Jach, H. Tommerup, J. Mundy, and J. Schell. 1992. Expression of a ribosome-inactivating protein leads to increased fungal protection in transgenic tobacco plants. Bio/Technology 10:305-308.

Lorberth, R., C. Dammann, M. Ebneth, S. Amati, and J.J. Sanchez-Serrano. 1992. Promoter elements involved in environmental and developmental control of potato proteinase inhibitor II expression. Plant J. 2:477-486.

Mariani, C., M. De Beuckeleer, J. Truettner, J. Leemans, and R.B. Goldberg. 1990. Induction of male sterility in plants by a chimaeric ribonuclease gene. Nature 347:737-741.

Martin, G.B. S.H. Brommonschenkel, J. Chunwongse, A. Frary, M.W. Ganal, R. Spivey, T. Wu, E.D. Earle, and S.D. Tanksley. 1993. Map-based cloning of a protein kinase gene conferring disease resistance in tomato. Science 262:1432-1436.

McKersie, B.D., Y. Chen, M. de Beus, S.R. Bowley, C. Bowler, D. Inze, K. D'Halluin, and J. Botterman. 1993. Superoxide dismutase enhances tolerance of freezing stress in transgenic alfalfa (Medicago sativa L.). Plant Physiol. 103:1155-1163.

Meyer, P., F. Linn, I. Heidmann, H. Meyer, I. Niedenof, and H. Saedler. 1992. Endogenous and environmental factors influence $35 \mathrm{~S}$ promoter methylation of a maize A1 gene construct in transgenic petunia and its colour phenotype. Mol. Gen. Genet. 231:345-352.

Micallef, B.J., K-S. Roh, and T.D. Sharkey. 1993. Altering photosynthetic performance in plants by genetically manipulating sucrose biosynthesis. Plant Physiol. Suppl. 102:32.

Mills, D., F.A. Hammerschlag, R.O. Nordeen, and L.D. Owens. 1994. Evidence for the breakdown of cecropin B by proteinases in the intercellular fluid of peach leaves. Plant Sci. 104:17-22.

Murata, N., W. Ishizaki-Nishizawa, S. Higashi, H. Hayashi, Y. Tasaka, and I. Nishida. 1992. Genetically engineered alterations in the chilling sensitivity of plants. Nature 356:710-713.

Murray, E.E., J. Lotzer, and M. Eberle. 1989. Codon usage in plant genes. Nucl. Acid Res. 17:477-498.

Oakes. J.V., C.K. Shewmaker, and D.M. Stalker. 1991. Production of cyclodextrins, a novel carbohydrate, in the tubers of transgenic potato plants. Bio/Technology 9:982-986.

Odell, J.T., F. Nagy, and N-H. Chua. 1985. Identification of DNA sequences required for activity of the cauliflower mosaic virus $35 \mathrm{~S}$ promoter. Nature 313:810-812.

Oeller, P.W., L. Min-Wong, L.P. Taylor, D.A. Pike, and A. Theologis. 1991.
Reversible inhibition of tomato fruit senescence by antisense RNA. Science 254:437-439.

Ohlrogge, J.B. 1994. Design of new plant products: Engineering of fatty acid metabolism. Plant Physiol. 104:821-826.

Okuley, J., J. Lightner, K. Feldmann, N. Yadav, E. Lark, and J. Browse. 1994. Arabidopsis FAD2 gene encodes the enzyme that is essential for polyunsaturated lipid synthesis. Plant Cell 6:147-158.

Otten, L., H. De Greve, J.P. Hernalsteens, M. Van Montagu, O. Schieder, J. Straub, and J. Schell. 1981. Mendelian transmission of genes introduced into plants by the Ti plasmids of Agrobacterium tumefaciens. Mol. Gen. Genet. 183:209-213.

Owens, L.D. and T. Heutte. 1994. Degradation of cecropin B and an analogous polypeptide by proteases in leaf intercellular fluids of various crops: Implications for cecropin accumulation in transgenic plants. Abstr. VIII Intl. Congr. Plant Tissue Cell Cult. p. 130.

Penarrubia, L., R. Kim, J. Giovannoni, S.-H. Kim, and R.L. Fischer. 1992. Production of the sweet protein monellin in transgenic plants. Bio/Technology 10:561-564.

Perlak, F.J., R.L. Fuchs, D.A. Dean, S.L. McPherson, and D.A. Fischhoff. 1991. Modification of the coding sequence enhances plant expression of insect control protein genes. Proc. Natl. Acad. Sci. USA 88:3324-3328.

Poirier, Y., D.E. Dennis, K. Klomparens, and C. Somerville. 1992. Polyhydroxybutyrate, a biodegradable thermoplastic, produced in transgenic plants. Science 256:520-523.

Raghothama, K.G., D. Liu, D.E. Nelson, P.R. Hasegawa, and R.A. Bressan 1993. Analysis of an osmotically regulated pathogenesis-related osmotin gene promoter. Plant Mol. Biol. 23:1117-1128.

Rocha-Sosa, M., R. Sonnewald, W. Frommer, M. Stratmann, J. Schell, and L. Willmitzer. 1989. Both developmental and metabolic signals activate the promoter of a class I patatin gene. EMBO J. 8:23-29.

Sheehy, R.E., M. Kramer, and W.R. Hiatt. 1988. Reduction of polygalacturonase activity in tomato fruit by antisense RNA. Proc. Natl. Acad. Sci. USA 85:8805-8809

Sijmons, P.C., B.M.M. Dekker, B. Schrammeijer, T.C. Verwoerd, P.J.M. Van Den Elzen, and A. Hoekema. 1990. Production of correctly processed human serum albumin in transgenic plants. Bio/Technology 8:217-221.

Smigocki, A., J.W. Neal, Jr., I. McCanna, and L. Douglass. 1993. Cytokininmediated insect resistance in Nicotiana plants transformed with the ipt gene. Plant Mol. Biol. 23:325-335.

Smith, C.J.S., C.F. Watson, J. Ray, C.R. Bird, P.C. Morris, W. Schuch, and D. Grierson. 1988. Antisense RNA inhibition of polygalacturonase gene expression in transgenic tomatoes. Nature 334:724-726.

Stalker, D.M., K.E. McBride, and L.D. Malyj. 1988. Herbicide resistance in transgenic plants expressing a bacterial detoxification gene. Science 242:419-423.

Stark, D.M., K.P. Timmerman, G.F. Barry, J. Preiss, and G.M. Kishore. 1992. Regulation of the amount of starch in plant tissues by ADP glucose pyrophosphorylase. Science 258:287-292.

Streber, W.R. and L. Willmitzer. 1989. Transgenic tobacco plants expressing a bacterial detoxifying enzyme are resistant to 2,4-D. Bio/Technology 7:811-816.

Tarczynski,M.C.,R.G.Jensen, andH.J.Bohnert. 1993. Stress protection of transgenic tobacco by production of the osmolyte mannitol. Science 259:508-510.

Taylor, J.L., J.D.G. Jones, S. Sandler, G.M. Mueller, J. Bedbrook, and P. Dunsmuir. 1987. Optimizing the expression of chimeric genes in plant cells. Mol. Gen. Genet. 210:572-577.

Vaeck, M., A. Reynaerts, H. Hofte, S. Jansens, M. De Beuckeleer, C. Dean, M. Zabeau, M. Van Montagu, and J. Leemans. 1987. Transgenic plants protected from insect attack. Nature 328:33-37.

Van Camp, W., H. Willekens, C. Bowler, M. Van Montagu, D. Inze, P. Reupold-Popp, H. Sandermann, Jr., and C. Langebartels. 1994. Elevated levels of superoxide dismutase protect transgenic plants against ozone damage. Bio/Technology 12:165-168.

Vandekerckhove, J., J. Van Damme, M. Van Lijsebettens, J. Botterman, M. De Block, M. Vandewiele, A. De Clercq, J. Leemans, M. Van Montagu, and E. Krebbers. 1989. Enkephalins produced in transgenic plants using modified 2S seed storage proteins. Bio/Technology 7:929-932.

van Kan, J.A.L., M.D. van de Rhee, D. Zuidema, B.J.C. Cornelissen, and J.F Bol. 1989. Structure of tobacco genes encoding thaumatin-like proteins. Plant Mol. Biol. 12:153-155.

Voelker, T.A., A.C. Worrell, L. Anderson, J. Bleibaum, C. Fan, D.J. Hawkins, S.E. Radke, and H.M. Davies. 1992. Fatty acid biosynthesis redirected to medium chains in transgenic oilseed plants. Science 257:72-73.

Wong, E.Y., C.M. Hironaka, and D.A. Fischhoff. 1992. Arabidopsis thaliana small subunit leader and transit peptide enhance the expression of Bacillus thuringiensis proteins in transgenic plants. Plant Mol. Biol. 20:81-93.

Xu, Y., P-F.L. Chang, D. Liu, M.L. Narasimhan, K.G. Raghothama, P.M Hasegawa, and R.A. Bressan. 1994. Plant defense genes are synergistically induced by ethylene and methyl jasmonate. Plant Cell 6:1077-1085. 